Role of Money in the Monetary Policy: A New Keynesian and New Monetarist Perspective

Masudul Hasan Adil and Neeraj R. Hatekar and Taniya Ghosh

Indira Gandhi Institute of Development Research, Mumbai January 2020 


\title{
Role of Money in the Monetary Policy: A New Keynesian and New Monetarist Perspective
}

\author{
Masudul Hasan Adil and Neeraj R. Hatekar and Taniya Ghosh
}

Email(corresponding author): adilmasood.alig@gmail.com

\begin{abstract}
In the recent scenario, one of the most pertinent changes in monetary economics has been the virtual disappearance of what was once a dominant focus, the role of money in monetary policy, and in parallel, the disappearance of the LM curve. Economists used to think about issues of monetary policy with the help of the LM curve as being part of the analytical framework which captures the demand for money. However, the workhorse model of modern monetary theory and policy, the New Keynesian Dynamic Stochastic General Equilibrium framework only comprises of, a dynamic aggregate demand (or the dynamic IS) curve, an aggregate supply (or the New Keynesian Phillips) curve, and a monetary policy rule. The monetary policy rule is generally the Taylor rule that relates the nominal interest rate to the output gap and inflation gap, but typically not to either the quantity or the growth rate of money. This change in the modern monetary model reflects how the central banks make monetary policy now. The present study provides a detailed discussion on the role of money in monetary policy formulation, in the context of New Keynesian and New Monetarist perspective. The pros and cons of abandonment of money or the LM curve from monetary policy models have been discussed in detail.
\end{abstract}

Keywords: Money, DSGE, New Keynesian, new monetarist, LM curve and Monetary policy JEL Code: E41, E43, E52, E58 


\title{
Role of Money in the Monetary Policy: A New Keynesian and New Monetarist Perspective
}

\author{
Masudul Hasan Adil \\ Corresponding Author, Mumbai School of Economics and Public-Policy, University of Mumbai, Mumbai- \\ 400098, India. Email id: adilmasood.alig@gmail.com
}

Neeraj R. Hatekar

Mumbai School of Economics and Public-Policy, University of Mumbai, Mumbai-400098. Email id: neeraj.hatekar@gmail.com

\author{
Taniya Ghosh
}

Indira Gandhi Institute of Development Research (IGIDR), Gen. A. K. Vaidya Marg, Filmcity Road Mumbai, 400065, India, Email Add.: taniya@igidr.ac.in, Tel.:91-22-28426536

\begin{abstract}
In the recent scenario, one of the most pertinent changes in monetary economics has been the virtual disappearance of what was once a dominant focus, the role of money in monetary policy, and in parallel, the disappearance of the LM curve. Economists used to think about issues of monetary policy with the help of the LM curve as being part of the analytical framework which captures the demand for money. However, the workhorse model of modern monetary theory and policy, the New Keynesian Dynamic Stochastic General Equilibrium framework only comprises of, a dynamic aggregate demand (or the dynamic IS) curve, an aggregate supply (or the New Keynesian Phillips) curve, and a monetary policy rule. The monetary policy rule is generally the Taylor rule that relates the nominal interest rate to the output gap and inflation gap, but typically not to either the quantity or the growth rate of money. This change in the modern monetary model reflects how the central banks make monetary policy now. The present study provides a detailed discussion on the role of money in monetary policy formulation, in the context of New Keynesian and New Monetarist perspective. The pros and cons of abandonment of money or the LM curve from monetary policy models have been discussed in detail.
\end{abstract}

JEL Classification: E41, E43, E52, E58

Keywords: Money, DSGE, New Keynesian, new monetarist, LM curve and Monetary policy 
"No proposition in macroeconomics has received more attention than that there exists, at the level of the aggregate economy, stable demand for money function."

Laidler, D. (1982), p. 39

\section{Introduction}

The money market is a steppingstone of all theories which tries to explain the evolution of aggregate economic activities. An accurate understanding of the money market is essential for both the analysis of past monetary policies and the formulation of appropriate contemporary policy (Goldfeld, 1973). The present study emphasizes on one aspect of the money market, the demand side, and surveys an extensive review of the current state of the art concerning the role of money demand function (MDF hereafter) or money or LM curve in the monetary policy. In most of the theories of macroeconomic behavior, the relation between the MDF and its determinants is a fundamental building block. Being a critical component in the formulation of an effective monetary policy, it is unsurprising that MDF has been subjected to extensive empirical scrutiny.

The IS-LM synthesis or Hicks-Hansen synthesis developed by Hicks (1937) and Hansen $(1949,1953)$ has remained the backbone of monetary policy. The extended IS-LMknown as the neoclassical synthesis or, later, the Aggregate Supply-Aggregate Demand model-helped to develop large macro-econometric models. More generally, the IS-LM framework has been an important one for understanding the short-run fluctuations in economic activities and money is one of its main building blocks. The model helps in understanding the role of money in the monetary policy, for instance, how the money demand helps to transmit the monetary policy shocks to the real sector.

The IS-LM model has been a cornerstone in macroeconomics teaching and policymaking for over half a century. However, various criticisms have been made on this model such as the model lacks microeconomic foundations, assumes price stickiness, has no role for expectations, and simplifies the economy's complexities to a handful of crude aggregate relationships. In addition to it, the recent developments in the modern macroeconomics have created new difficulties for IS-LM framework such as virtual disappearance of focus on the role of money as a part of the analytical framework. The alternative replaces the LM curve, along with its assumption that the central bank targets the money supply, with an assumption that the central bank follows a real interest rate rule (Romer, 2000).

Today the policymakers pay no attention to money and mainly focus on interest rates. Therefore, often the current "monetary policy" is called as "interest rate policy". Woodford (2000) mentions that money is irrelevant for the conduct of an effective monetary policy: "even if the demand for base money for use in facilitating transactions is largely or even completely eliminated, monetary policy should continue to be effective." This is because central banks could continue macroeconomic stabilization by controlling "a short-term nominal interest rate, and this would continue to be possible, in particular through the use of a 'channel' system for the implementation of policy, like those currently used in Canada, Australia, and New Zealand." Similarly, Svensson (2008) argued that over the last 50 years, 
central banks, policymakers, and monetary theorists have experienced that "monetary aggregates matter little, or even not at all, for monetary policy.",

The New Keynesian (NK hereafter) framework provides the foundations of the NK DSGE (dynamic stochastic general equilibrium) model which is the workhorse model for the analysis of monetary policy in major central banks. It is mainly a three equations model derived from optimizing the behavior of households and firms, and based on the assumption of rational expectations and market clearing. Furthermore, under this framework firms are modeled as monopolistic competitors and the assumption of nominal rigidity introduces nonneutrality feature of monetary policy to the model (Walsh, 2017). The NK DSGE model can briefly be summed up as follows:

The first equation is the dynamic aggregate demand curve or the dynamic IS equation derived from inter-temporal maximization of the representative agents, who maximizes a utility function subject to a resource constraint. The dynamic IS equation shows a negative association between output and inflation. Its downward slope reflects monetary policy and demand for goods and services: a high level of inflation causes the central bank to raise nominal and real interest rates, which in turn reduces the demand for goods and services. The dynamic IS equation is given by,

$$
Y_{t}=\bar{Y}_{t}-\left[\alpha \theta_{\pi} /\left(1+\alpha \theta_{y}\right)\right]\left(\pi_{t}-\pi_{t}^{*}\right)+\left[1 /\left(1+\alpha \theta_{y}\right)\right] \varepsilon_{t}
$$

Where, $Y_{t}$ is the total output of goods and services, $\bar{Y}_{t}$ is the natural level of output in the economy, $\pi_{t}$ is the current inflation, $\pi_{t}^{*}$ is the target rate of inflation of a central bank. The $\varepsilon_{t}$ is a random demand shock to the goods and services and $\alpha$ is the parameter which shows the responsiveness of the demand for goods and services to the real interest rate; also it is greater than zero. Lastly, $\theta_{\pi}$ and $\theta_{y}$ are two key policy parameters (assumed to be greater than zero) which indicate how much the central bank allows the interest rate target to respond to fluctuations in inflation and output, respectively. This equation relates output $\left(Y_{t}\right)$ to inflation $\left(\pi_{t}\right)$ for given values of three exogenous variables $\left(\bar{Y}_{t}, \pi_{t}^{*}\right.$ and $\left.\varepsilon_{t}\right)$.

The second equation is the New Keynesian Phillips Curve (NKPC) or dynamic aggregate supply curve or price-setting curve. Its upward slope reflects the Phillips curve relationship: Other things equal, high levels of economic activity are associated with high inflation. Its functional form is represented below.

$$
\pi_{t}=\pi_{t-1}+\phi\left(Y_{t}-\bar{Y}_{t}\right)+v_{t}
$$

The equation reflects, inflation $\left(\pi_{t}\right)$ depends on previously expected inflation $\left(\pi_{t-1}\right)$, the deviation of output from its natural level $\left(Y_{t}-\bar{Y}_{t}\right)$, and an exogenous supply shock $\left(v_{t}\right) . \phi$ denotes the responsiveness of inflation to output in the Phillips curve which is greater than zero. 
Lastly, the model is completed by the Taylor rule or interest rate reaction function or monetary policy rule - which relates the nominal interest rate to variables like output and inflation gap but typically not either the quantity or the growth rate of money. How would the central bank set the interest rates to achieve low and stable inflation while avoiding large fluctuations in output and employment? One such way to do this is by using the Taylor rule, in which, central banks decide exactly how much to respond to changes in inflation and real economic activity; whose functional form is as follows.

$$
i_{t}=\pi_{t}+\rho+\theta_{\pi}\left(\pi_{t}-\pi_{t}^{*}\right)+\theta_{y}\left(Y_{t}-\bar{Y}_{t}\right)
$$

Where, $i_{t}$ is the nominal rate of interest and $\rho$ is the constant in this equation which depicts the natural rate of interest. Thus, these three equations complete the discussion of the NK framework.

However, despite knowing the intimate link between money and prices, most of the economists and central bankers conduct their conversations in terms of interest rates and not the quantity of money. This is so because of unpredictable shifts in the money demand, which posits that central banks should choose to set interest rates and allow the public to determine the money supply - which can be supplied at the given rate of interest. Thus, the changes in the standard macro model reflect how most of the central banks make monetary policy in the current scenario. However, this is one extreme school of thought-"New Keynesian economics" 3 - which favors the disappearance of the LM curve from monetary policy. Contrary to it, another extreme school of thought - the "New Monetarist economics"4 which favors the importance of LM curve; i.e., they try to maintain that the role of MDF into monetary policy.

In the backdrop of the above rationale, this paper attempts to flourish the theoretical discussion and debate on the role of money or MDF or LM curve in monetary policy. It might be useful to have such discussions, particularly now because the policymakers and macroeconomists ignore the role of money and frequently switch from conventional to unconventional monetary policies ${ }^{5}$ in an effort to make emphasis on the effectiveness of their interest rate policies. Henceforth, the present study surveys the literature on the role of money to know the effectiveness of this macro variable in monetary policy.

Section 1 focusses on the role of money in monetary policy. It briefly discusses the NK DSGE framework of monetary policy. Then, it addresses the takeaway of two different schools of thought over the role of money. Section 2 presents the theoretical account for New Keynesian and New Monetarist's views on the role of money in the monetary policy. Section 3 discusses the two approaches for the role of money. Section 4 reviews the literature on the role of money. Lastly, section 5 represents summary and concluding remarks of the study.

\section{Theoretical Accounts}

There is a paradox in the role of money in economic policymaking. Money was the main focus of the earlier central banks, however, the main objective of today's central banks is recognized as price stability. It happened so due to the failure of money as a causal factor 
for inflation, particularly during the post-war period. However, later on, money started returning as a cornerstone in economic policy. This could have been possible because of the counter-revolution of the concept of "non-neutrality of money"6 given by Keynesian economists and later on justified by NK economists by providing micro-foundations behind its rationale. This counter-revolution has broken down the idea of "classical dichotomy"7. In this fashion, money has come up as one of the building blocks of monetary policy. As Milton Friedman argued, "inflation is always and everywhere a monetary phenomenon." Since inflation is treated as monetary phenomenon then controlling the money supply is considered as a route cause for low inflation. Consequently, monetary aggregates became central to the conduct of monetary policy.

However, lowering inflation proved painful. Adding to the agony, the monetary aggregates did not respond kindly to the attempts made by central banks to control them. It is so because MDF became unstable in the late 1970s and 1980s due to financial liberalization that took place across the globe. Therefore, the focus towards monetary aggregates as an intermediate target variable fainted out. Consequently, the later writings of NK economistssuch as Woodford (2008); Svensson (2008); Romer (2000); and Clarida, Gali, and Gertler (1999) - de-emphasized the role of monetary aggregates. Most of the central banks switched over from monetary aggregates targeting to the interest rate targeting. As the Governor of the Bank of Canada at the time, Gerald Bouey remarked, "We did not abandon the monetary aggregates, they abandoned us".

Nevertheless, the supporter of New Monetarist economics-for instance, Nelson (2008); Goodhart (2007); Ball (2012); Thornton (2014); Friedman (2003); King (2001) and Barnett (1997) - defined money as an indispensable variable for the implementation of monetary policy. They are of the view that the role of money is the building block of monetary policy. Money being a steppingstone in the formulation of monetary policy, the profession, however, is yet to develop a model useful for formulating and understanding monetary policy. The branch of the profession is called "New Monetarist economics".

\section{Two Approaches to the Role of Money in Monetary Policy}

The role of money in monetary policy can be analyzed through two different perspectives. In the first perspective, it has been viewed that monetary policymakers are achieving their long-run inflation goal in one of the best possible ways by determining and achieving an appropriate growth rate for money supply. The existence of a monetary aggregate with a stable and causal relationship to inflation that the central bank can control over the medium-to-long-run reflects the usefulness of the monetary aggregate approach (Kahn and Benolkin, 2007). As Taylor (1993) advised: "The evidence that the large swings in inflation are related to money growth indicates, however, that money should continue to play an important role in monetary policy formulation in the future."

To examine the role of money, we need to know the quantity theory of money, which has its roots in the work of the early monetary theorists, including the philosopher and economist David Hume (1711-1776) ${ }^{8}$. It is given by the following equation, 


$$
P_{t} Q_{t}=M_{t} V_{t}
$$

Where $P_{t}$ depicts the price of a typical transaction - the number of money exchanged. $Q_{t}$ is the real output, $M_{t}$ denotes the quantity of money. $V_{t}$ is the transactions velocity of money. As equation of exchange depicts, nominal spending (defined as price level multiplied by real output) is supported by a given money stock times the velocity of money-measures the turnover rate at which money circulates in an economy.

If we take growth rates of this identity (where lower case letters depict the rates of change of upper case letters) then we get the following representation:

$$
p_{t}+q_{t}=m_{t}+v_{t}
$$

Money growth determines the nominal spending growth $\left(p_{t}+q_{t}\right)$, provided the velocity is stable and predictable over time. In the long-run, velocity depends upon the transactions technologies that determine how much money is required in an economy to facilitate a given level of economic activity. For instance, due to the emergence of financial innovation, which allows a given money stock to support more number of transactions and a higher level of nominal spending, the velocity has increased. If the use of transactions technologies have smoothly evolved over time, then the velocity growth is more likely to be stable and predictable.

Rearranging the terms, we get,

$$
p_{t}=m_{t}-q_{t}+v_{t}
$$

Given a reliable estimate of the economy's long-run growth potential (which is determined by growth in the labor force and growth in productivity and is independent of monetary policy), policymakers can achieve a given long-run inflation objective provided they can achieve a particular, corresponding growth rate of the supply of money (Kahn and Benolkin, 2007).

In the second perspective, it has been viewed that policymakers are achieving their inflation goal, one of the best possible way, by setting out short-term interest rates to achieve an implicit or explicit inflation objective, without even bothering about monetary aggregates. The interest rate approach requires pre-requisite that policymakers be able to influence expectations of future short-term interest rates and reliably estimate the effect of expected interest rate movements on economic activity and inflation (Kahn and Benolkin, 2007).

Nowadays, the use of interest-rate operating instrument in the decision-making of inflation-targeting central banks deserves much attention. The ease with which the second approach hits the macroeconomic goal variables reflects the intense criticism of the first approach. Such as the European Central Banks's assignment of a prominent role to money being the basis for sharp criticism from a number of economists (see for instance Gali, 2002). 


\section{Survey of Literature on the Role of Money}

In the 1960s and 1970s, a plethora of studies estimated MDF which could fit the historical data. As per the money demand specification of Goldfeld's (1973), the long-run demand for real money balance depends upon aggregate output and one or more short-term interest rates. Shortly after that, however, Goldfeld (1976) mentioned the failure of his money demand specification, known as the "case of missing money", in which MDF greatly overpredicted the growth of narrow money. Further research uncovered another problem: when the sample period was extended to 1979 or later, the estimated adjustment speed of money holding was close to zero (Goldfeld and Sichel, 1990). These findings led to a search for the well-established and stable specification of MDF by using different measures of the key variables, various functional forms, a generalization of the partial adjustment model, different proxies for financial liberalization, etc. In the search for a stable MDF, the whole literature bifurcated into two different schools of thought, New Keynesian economics and New monetarist economics.

\subsection{Money: reasons for its irrelevance}

Thornton (2014) highlighted several possible reasons behind money's irrelevancy. First, the empirical relevance of money supply for economic activity and price level-slowly and gradually declined since the late 1970s and 1980s. Second, money has evolved from being a full-bodied commodity-having intrinsic value such as gold and silver, to fiat money-intrinsically worthless papers and coins. As argued by several prominent macroeconomists, for instance, King (1999), that society will move towards cashless economy - a monetary system with an arbitrary unit of account that is not linked to a physical object like currency, rather a transaction would be made by internet banking, different payment applications and another cyber mechanism. Third, the fact that many if not most transactions are facilitated using credit and other forms of electronic transactions appears to have intensified the view that money is merely an accounting device.

Furthermore, the velocity of money began fluctuating erratically in the late 1970s and 80s (Friedman, 1988) and most of the economists found that the short-run behavior of MDF is unstable and mysterious. However, the stability of short-run MDF is the pre-requisite for an effective role of money in monetary policy. Consequently, the Fed ignored targeting money supply and set interest rates based on inflation and output throughout the 1990s and 2000s.

\section{The irrelevance of money in macro-econometric models}

Many macroeconomists found it difficult to include money in economic models in order to reflect the essential role of money in economic activity and economic welfare. In particular, the NK model does not explicitly include money. This implies that while monetary policy is essential in the determination of prices, money is not. But prices of goods are stated in terms of the monetary unit, and consequently so too is the price level (Thornton, 2014). This means that the price level may not be determined independently of the money supply. 
This fact is not necessarily reflected by the NK model. The model suggests that a huge increase in the monetary base will represent inflationary pressure only if the decline in the rate of interest enhances the spending enough to make closer the gap between actual and potential output. Thus, money is irrelevant under the NK framework: monetary policy works primarily, if not exclusively, through the interest rate channel, that is, policymakers control the overnight (short-term) policy rate, which affects the entire structure of risk-free and risky interest rates, which in turn affects aggregate demand, economic activities, and inflation. In a nutshell, given prominence to NK economists and lack of focus to the role of money, one might think that it is foolish to emphasize that money is essential for economic activities and for determining the price level. But one should not forget the argument made by Thornton (2014) that "it will no doubt seem even more foolish to suggest that monetary policymakers' ability to influence interest rates, especially those that matter for the efficacy of monetary policy, is greatly exaggerated."

\subsection{Money: reasons for its relevance with a theoretical perspective}

Many theories have incorporated money in economic models by including money in a household's utility function or a producer's production function. McCallum (2008) accepts that money is not explicitly addressed in the NK model rather it is implicitly incorporated into the model. As Thornton (2014) quoted McCallum (2008), money is required because "it is not clear that the central bank can control the interest rate(s) of macroeconomic importance - $R_{t}$ in Eq. (1) [the IS equation] - in a world in which there is no monetary aggregate that facilitates transactions and hence serves as the dominant medium of exchange and, as a consequence, also become the medium of account." 9 The fact that the NK model does not explicitly include money and credit markets make it less useful for analyzing the effectiveness of the central banks' large-scale asset purchases. ${ }^{10}$

Most of the transactions are facilitated by credit and other forms of electronic devices. But the predominance of credit is due to the existence of money. Credit is merely the intertemporal exchange, exchanging something today for the promise to receive something else or the same thing at future date. The use of credit is facilitated by money because the credit contracts are denominated in terms of money, for instance, loans are made in money form, also the principal and interest amount are being paid in terms of money. Thus, transactions which are facilitated with credit do not eliminate the essential role of money in economic activity.

According to Friedman (2003), the disappearance of the LM curve has left two lacunae in how economists think about monetary policy. First, it is more difficult to take into account how the functioning of the banking system matters for monetary policy. Second, the underlying question of how the central bank manages to fix the chosen interest rate without the LM curve. Furthermore, Friedman (2003) mentions that in the world of monetary policy with no money demand, "the difficult challenge will be to understand the relationships between what individual households and firms and banks and asset management firms dorearranging their portfolios, making and taking loans, buying and selling equities and perhaps foreign currencies, investing in physical assets, buying and selling real goods and services, 
hiring and selling labour, and setting prices and wages, all in ways that somehow depend in part on the interest rates that central banks set-and the observable influence of monetary policy on such features of the aggregate economy as output and employment and inflation".

Christiano et al. (2007) showed that monitoring money and credit can help anchor private-sector expectations about inflation. They also showed that monetary policy with a narrow focus on inflation can lead to welfare-reducing boom-bust cycles in real and financial variables. King (2001) mentioned that although the clarity of a single pillar - an inflation targeting - to dual pillars is preferable, there are dangers in ignoring the special role of money. Ball (2012) favors the role of money in monetary policy after showing stable money demand in case of U.S. by emphasizing the choice of the interest rate. Importantly, the concept of Barnett critique is quite pertinent in the discussion of monetary policy without the LM curve. Barnett (1997) argued that internal inconsistency between the aggregation theory used to produce monetary aggregates and the economic theory used to produce the models within which the aggregates are used are responsible for the appearance of unstable demand and supply for money. Hence, the instability in the money demand may be of conceptual flaw rather than the real phenomenon. Finally, Thornton (2014) argues various rationale behind the role of money, such as (i) money exists for the simple reason that it is the most efficient method of achieving final payment in exchange; (ii) the existence of money is essential for the development of goods and financial markets; (iii) a marked deterioration in the moneypayment system would "cripple" economic activity and (iv) money is essential for economic activity and for the determination of the price level. ${ }^{11}$

\subsection{Money: reasons for its relevance with an empirical perspective}

Baba et al. (1992) estimated U.S. M1 demand functions for the period 1960-1988, which was supposed to appear unstable and regularly "breaking down" (due to issues of missing money, great velocity decline, M1-explosion, etc.). They re-estimated MDF by including inflation, real income, long-term bond yield and risk, T-bill interest rates, and learning curve weighted yields on M1 and non-transactions M2. The model estimated using the dynamic error-correction form and the alternative specifications explains the earlier "breakdowns", showing the model's distinctive features to be important in accounting for the data. Similarly, Ball (2012) challenges the conventional wisdom of unstable MDF in the short-run by finding a stable MDF for M1 in the U.S. for a period 1959-1993. The application of Goldfeld's partial-adjustment model for short-run dynamics and co-integrating relation for long-run MDF depict the existence of stable money demand in the U.S. Finally, Kumar and Webber (2013) investigate the demand for M1 for Australia and New Zealand over the period 1960-2009. The regime shift in the money demand is found for both countries. It is shown that M1 became unstable for the period 1984-1998 for both the countries, although tests for stability are not rejected thereafter. 


\section{Summary and Concluding Remarks}

The role of money is inevitable in the conduct of effective monetary policy. Understanding the role of money demand becomes necessary when a central bank "unwinds" a policy of zero interest rates and quantitative easing, as it can tell how much the central bank must shrink the money supply to raise interest rates above zero (Ball, 2012) and hence, how much the central bank must reduce the monetary base given the money multiplier.

Most of the current economists believe that central bank should set interest rate by paying less attention to the behavior of monetary aggregates (except possibly at the zero bound on interest rates). However, this consensus is based on the view that MDF is unstable. But, on behalf of surveyed literature - which shows that MDF is well-behaved in various economies particularly after the $1990 \mathrm{~s}^{12}$ — present study suggests that we should reopen the policy question and the role of money in the monetary policy should be re-examined.

Thus, present study supports the arguments made by New Monetarist economists-in favor of the role of money in the conduct of monetary policy. This conclusion is inclined with the monetary policy strategy of the European Central Bank (ECB). As mentioned by Pospisil (2017), "price stability being a major concern, the Governing Council of the ECB has decided to accord broad monetary aggregate M3 prominent importance in the Euro system's monetary policy strategy by announcing a reference value for its annual growth rate." Consequently, the ECB analyses, along with other economic indicators, the development of monetary aggregates. The policy implications of this conclusion, based on theoretical arguments, may be considered in the following fashion: the central bank may consider monetary aggregates as an indicator or nominal anchor in order to achieve its ultimate macroeconomic goals, i.e. flexible inflation targeting. "New Monetarist economics" is attempting to build models based on microeconomic foundations (Williamson and Wright; 2010), useful for formulating and understanding the role of money in monetary policy. But their contribution is yet to be taken seriously.

\section{Endnotes}

1. Woodford (2000).

2. Svensson (2008, p.4).

3. For an extensive view on the LM curve from New Keynesian perspective, see Woodford (2000, 2008); Svensson (2008); Romer (2000); and Clarida, Gali, and Gertler (1999).

4. For an extensive view on the LM curve from New Monetarist economics perspective, see Nelson (2008); Goodhart (2007); Ball (2012); Thornton (2014); Friedman (2003); Williamson and Wright (2010); King (2001); McCallum (2008); and Barnett (1997).

5 . When the policy rates are at (near) zero, the conventional instrument of monetary policy, the interest rate, becomes ineffective. The central banks go for unconventional monetary policies, for instance, quantitative easing, credit easing, forward guidance, and helicopter money.

6. In the short-run, money affects real variables such as the level of output and employment due to the assumption of nominal wage and price rigidity.

7. The theoretical separation of real and nominal variables (Mankiw, 2007).

8. Mankiw (2007), p. 83. 
9. McCallum (2008, p. 1789), parentheses added.

10. Thornton (2014) gave an example of IS/LM model when Hicks omitted the bond market due to Walras' Law. However, such modification in the model was ill-suited for analyzing fiscal deficit issues.

11. Thornton (2014, p. 211)

12. Importantly, existence of stable MDF after 1990s is argued on the ground of estimating MDF after incorporating financial innovation-which has started in the late 1970s and 80s across the globe. Some studies have already shown the stable MDF in this fashion, for instance, James (2005), Dekle and Pradhan (1999).

\section{References}

Baba, Y., Hendry, D. F., \& Starr, R. M. (1992). The demand for M1 in the USA, 1960-1988. The Review of Economic Studies, 59(1), 25-61.

Ball, L. (2012). Short-run money demand. Journal of Monetary Economics, 59(7), 622-633.

Barnett, W. A. (1997). Which road leads to stable money demand? The Economic Journal, 107(443), 1171-1185.

Christiano, L., Motto, R., \& Rostagno, M. (2007). Two reasons why money and credit may be useful in monetary policy. National Bureau of Economic Research.

Clarida, R., Gali, J., \& Gertler, M. (1999). The science of monetary policy: a new Keynesian perspective. Journal of Economic Literature, 37(4), 1661-1707.

Dekle, R., \& Pradhan, M. (1999). Financial liberalization and money demand in the ASEAN countries. International Journal of Finance \& Economics, 4(3), 205-215.

Friedman, B. (2003). The LM curve: a not-so-fond farewell. National Bureau of Economic Research.

Friedman, B. M. (1988). Lessons on Monetary Policy from the 1980s. Journal of Economic Perspectives, 2(3), 51-72.

Galí, J. (2002). Monetary policy in the early years of EMU. EMU and Economic Policy in Europe, Cheltenham.

Galí, J. (2015). Monetary policy, inflation, and the business cycle: an introduction to the new Keynesian framework and its applications. Princeton University Press.

Goldfeld, S. M., Duesenberry, J., \& Poole, W. (1973). The demand for money revisited. Brookings Papers on Economic Activity, 1973(3), 577-646.

Goldfeld, S. M., Fand, D. I., \& Brainard, W. C. (1976). The case of the missing money. Brookings Papers on Economic Activity, 1976(3), 683-739.

Goldfeld, S. M., \& Sichel, D. E. (1990). The demand for money. Handbook of Monetary Economics, 1, 299-356.

Goodhart, C. (2007). Whatever became of the monetary aggregates? National Institute Economic Review, 200(1), 56-61.

Hansen, Alvin H. (1949). Monetary theory and fiscal policy. Mcgraw-Hill Kogakusha, Ltd; London.

Hansen, Alvin Harvey. (1953). A Guide to Keynes. New York: McGraw Hill.

Hicks, J. R. (1937). Mr. Keynes and the" classics"; a suggested interpretation. Econometrica: Journal of the Econometric Society, 147-159. 
James, G. A. (2005). Money demand and financial liberalization in Indonesia. Journal of Asian Economics, 16(5), 817-829.

Kahn, G. A., \& Benolkin, S. (2007). The role of money in monetary policy: why do the Fed and ECB see it so differently? Economic Review (Kansas City), 92(3), 5-37.

King, M. (1999). Challenges for monetary policy: new and old. Quarterly Bulletin-Bank of England, 39, 397-415.

King, M. (2001). No money, no inflation the role of money in the economy. Economie Internationale, (4), 111-131.

Kumar, S., \& Webber, D. J. (2013). Australasian money demand stability: application of structural break tests. Applied Economics, 45(8), 1011-1025.

Laidler, D. E. (1982). Monetarist perspectives. Harvard University Press.

Mankiw, G. (2007). Macroeconomics (Sixth edition). Worth Publishers.

McCallum, B. T. (2008). How important is money in the conduct of Monetary Policy? A Comment. Journal of Money, Credit and Banking, 40(8), 1783-1790.

Nelson, E. (2008). Why money growth determines inflation in the long run: Answering the Woodford critique. Journal of Money, Credit and Banking, 40(8), 1791-1814.

Pospisil, R. (2017). The Monetary Aggregates and Current Objectives of European Central Bank. Studia Prawno-Ekonomiczne, 105, 341-363.

Romer, D. H. (2000). Keynesian macroeconomics without the LM curve. Journal of Economic Perspectives, 14(2), 149-169.

Svensson, L. E. (2008). What have economists learned about monetary policy over the past 50 years. January.[Retrieved From].

Taylor, J. B. (1993). Discretion versus policy rules in practice. In Carnegie-Rochester conference series on public policy (Vol. 39, pp. 195-214). Elsevier.

Thornton, D. L. (2014). Monetary policy: Why money matters (and interest rates don't). Journal of Macroeconomics, 40, 202-213.

Walsh, C. E. (2017). Monetary theory and policy. MIT press.

Williamson, S., \& Wright, R. (2010). New monetarist economics: Models. In Handbook of Monetary Economics (Vol. 3, pp. 25-96). Elsevier.

Woodford, M. (2000). Monetary policy in a world without money. International Finance, 3(2), 229-260.

Woodford, M. (2008). How important is money in the conduct of monetary policy? Journal of Money, Credit and Banking, 40(8), 1561-1598. 